\title{
Homologi Gen Seleno Metiltransferase (smt) pada Geobacillus sp. 20k dengan smt Astragalus bisulcatus
}

\author{
Evi Triana, ${ }^{1}$ Imam Supardi, ${ }^{2}$ Sunarjati Soedigdoadi, ${ }^{2}$ Novik Nurhidayat ${ }^{3}$ \\ ${ }^{1}$ Program Magister, Program Studi Ilmu Kedokteran Dasar, ${ }^{2}$ Bagian Mikrobiologi \\ Fakultas Kedokteran, Universitas Padjadjaran, Bandung \\ ${ }^{3}$ Pusat Penelitian Biologi, LIPI, Cibinong
}

\begin{abstract}
Abstrak
Metil selenosistein (MSC) merupakan bentuk selenium yang paling efektif melawan sel kanker. Pembentukan MSC diperantarai oleh enzim seleno metiltransferase (disandi gen $s m t$ ) sebagai mekanisme detoksifikasi selenium dengan cara metilasi selenosistein. Gen smt telah dikarakterisasi dari tumbuhan yang kaya selenium, Astragalus bisulcatus. Dilakukan penelitian eksperimental laboratorik terhadap Geobacillus sp. 20k di Lembaga Ilmu Pengetahuan Indonesia (LIPI), Cibinong, Bogor, periode November 2008-Juni 2009. Gen smt dideteksi dengan polymerase chain reaction dan sekuensing. Sekuens fragmen DNA dianalisis menggunakan program basic local alignment search tool (BLAST). Hasil pencarian homologi menunjukkan gen smt dan homolognya pada umumnya terdapat pada tumbuhan pengakumulasi selenium, antara lain A. bisulcatus, $C$. sinensis, dan A. thaliana dengan kesamaan $>85 \%$. Primer yang didesain untuk amplifikasi $s m t$ adalah CAAGCCACCATTCAAGGTTT dan CCCTACTGATCCCGC AATTA. Hasil amplifikasi fragmen DNA didapatkan sekitar 190 base pair. Sekuens DNA dan translasi proteinnya teridentifikasi sebagai bagian dari enzim termofilik dan smt A. bisulcatus, dengan tingkat kesamaan $83 \%$ untuk gen smt dan 88-90\% untuk proteinnya. Disimpulkan Geobacillus sp. 20k memiliki gen serupa dengan gen smt $A$. bisulcatus sehingga pengembangan lebih lanjut sebagai sumber selenium nontoksik untuk terapi kanker perlu dipertimbangkan. [MKB.2010;42(3):128-34].
\end{abstract}

Kata kunci: Geobacillus sp. 20k, kanker, metilselenosistein, selenium nontoksik, seleno metiltransferase

\section{Homology of Seleno Methyltransferase (smt) Gene from Geobacillus sp. 20k with That from Astragalus bisulcatus}

\begin{abstract}
Methylselenocysteine (MSC) is the most effective form of selenium against cancer. The synthesis of MSC is catalyzed by seleno methyltransferase $(s m t)$ through selenium methylation as its detoxification mechanism. Gene of smt has been characterized in selenium rich plant, Astragalus bisulcatus. This experimental laboratoric study was done on Geobacillus sp. 20k. at Lembaga Ilmu Pengetahuan Indonesia (LIPI), Cibinong, Bogor, November 2008-June 2009. Target gene was detected by polymerase chain reaction and sequencing. DNA sequence was analyzed by the basic local alignment search tool (BLAST). The results showed that smt gene and its homolog were generally found on selenium rich plants, such as A. bisulcatus, $C$. sinensis, and $A$. thaliana, with similarity more than $85 \%$. Designed primers for amplification of $s m t$ are CAAGCCACCATTCAAGGTTT and CCCTACTGATCCCGC AATTA. Amplification of DNA fragments obtained at approximately 190 base pair. DNA sequence and its protein translation were identified as part of the thermophilic enzyme and smt of $A$. bisulcatus, with $83 \%$ similarity for smt genes and $88-90 \%$ for protein. In conclusion, Geobacillus sp. 20k have smt genes similar with that of $A$. bisulcatus, therefore further development of this isolate as a non toxic selenium source for cancer therapy could be taken into consideration. [MKB. 2010;42(3):128-34].
\end{abstract}

Key words: Cancer, Geobacillus sp. 20k, non toxic selenium, methyl selenocystein, seleno methyltransferase

Korespondensi: Evi Triana, Pusat Penelitian Biologi, Lembaga Ilmu Pengetahuan Indonesia (LIPI), jalan Raya Bogor km. 46, Cibinong, Bogor, telepon 08164869409,e-mail: evitriana03@yahoo.com 


\section{Pendahuluan}

Selenium memiliki nilai nutrisi yang penting bagi hampir semua mahluk hidup karena merupakan komponen kunci pada sejumlah selenoprotein fungsional yang dibutuhkan untuk kesehatan dan fungsi normal tubuh. Hal tersebut disebabkan selenium merupakan komponen inti dari banyak enzim, antara lain: glutationin peroksidase, format dehidrogenase, dan tioredoksin reduktase. ${ }^{1,2}$

Selenium memiliki potensi menguntungkan dalam bidang kesehatan, selain nilai nutrisinya yang penting,. ${ }^{3}$ Beberapa penelitian mengungkap peranan protektif selenium dalam melawan kanker, ${ }^{4}$ tetapi saat digunakan untuk tujuan terapi, perlu kehati-hatian untuk menghindari toksisitas selenium karena toksik pada konsentrasi tinggi. Kisaran dosis terapi (therapeutic window), yaitu dosis yang dibutuhkan sebagai kemopreventif dengan dosis toksik selenium, sangat sempit. ${ }^{5}$ Dosis selenium $200 \mu \mathrm{g} /$ hari dapat menurunkan kejadian kanker, ${ }^{3}$ sedangkan asupan selenium yang masih dapat ditoleransi sebesar $400 \mu \mathrm{g} / \mathrm{hari}^{5}{ }^{5}$ Oleh karena itu senyawa selenium yang tidak bersifat toksik sangat dibutuhkan agar terapi kanker menggunakan senyawa selenium menjadi lebih efektif.

Hasil penelitian yang terdahulu menunjukkan bahwa metil selenosistein (MSC) merupakan bentuk senyawa selenium yang paling efektif melawan sel kanker karena dapat menghambat siklus sel dan menginduksi apoptosis. ${ }^{6-8}$ Metil selenosistein juga dibuktikan dapat menurunkan toksisitas dan akumulasi selenium di dalam tubuh, ${ }^{9}$ oleh karena itu, senyawa tersebut sangat menguntungkan sebagai agen kemopreventif karena peningkatan akumulasi selenium dalam tubuh 5-10x lipat di atas level supranutrisi bersifat toksik. $^{10}$

Metil selenosistein dihasilkan dari mekanisme detoksifikasi selenium, yaitu dengan cara metilasi selenosistein untuk menghindari penggabungan yang nonspesifik dengan protein. Senyawa ini merupakan bentuk selenium yang disimpan dan hanya dihasilkan oleh organisme yang kaya selenium. ${ }^{10}$ Mekanisme tersebut dibuktikan dari hasil penelitian tumbuhan yang kaya selenium, Astragalus bisulcatus. Tumbuhan ini mampu bertahan terhadap toksisitas selenium oleh karena memiliki enzim seleno metiltransferase (SMT) yang berperan mentransfer gugus metil dari metilmetionin kepada selenosistein membentuk
MSC. ${ }^{11}$ Potensi ini dapat dimanfaatkan untuk memperoleh MSC dalam jumlah tinggi yang dapat digunakan untuk pencegahan dan terapi kanker. Untuk pengembangan MSC sebagai bahan kemoprotektif, perlu diketahui gen yang berperan dalam pembentukan senyawa selenium termetilasi tersebut.

Penelitian yang dilakukan oleh Ellis et al. ${ }^{1}$ mengungkapkan bahwa enzim SMT disandi oleh gen smt. Gen ini sebagian besar diekspresikan oleh tumbuhan yang kaya selenium, tetapi sampai saat ini belum dilaporkan adanya gen spesifik smt pada genom bakteri, termasuk bakteri termofilik. Untuk mengungkapkan kemungkinan adanya gen serupa smt pada bakteri dilakukan penelitian ini, yaitu untuk mengkaji keberadaan dan identitas gen yang menyandi enzim SMT pada isolat bakteri termofilik Geobacillus sp. 20k dengan cara analisis sekuens/urutan nukleotida bakteri tersebut.

Geobacillus sp. 20k dipilih karena tahan terhadap toksisitas selenium dan ekstrak selnya menunjukkan aktivitas antioksidasi dan induksi apoptosis. Selain lebih mudah dimanipulasi dan diproduksi secara cepat dalam jumlah banyak dibandingkan dengan sumber selenium nabati, bakteri termofilik juga memiliki gen yang stabil terhadap suhu tinggi dibanding bakteri lain, sehingga lebih mudah diaplikasikan dalam bidang bioteknologi dan industri untuk dikembangkan sebagai sumber selenium nontoksik alami untuk terapi kanker.

\section{Metode}

Bakteri ditumbuhkan pada media heterotrof agar yang ditambah 100 ppm $\mathrm{SeO}_{2}$, lalu diinkubasi pada suhu $60^{\circ} \mathrm{C}$ selama 3 hari. Selanjutnya bakteri ditumbuhkan kembali pada media heterotrof cair pada suhu $60^{\circ} \mathrm{C}$ selama 3 hari. Sel dipanen dengan cara sentrifugasi $3.000 \mathrm{rpm}$ selama 5-10 menit.

DNA diekstraksi dan dipurifikasi dengan menggunakan illustra ${ }^{\mathrm{TM}}$ bacteria genomic Prep Mini Spin Kit dari GE Healthcare menurut prosedur dari produsen.

Primer spesifik untuk gen smt didesain dengan menggunakan program primer 3 berdasarkan query nukleotida gen smt A. bisulcatus. Urutan nukleotida tersebut (Accession no. AJ131433) diperoleh dari Gene Bank NCBI secara online. ${ }^{12}$ Pasangan primer yang telah direkomendasikan 
ditentukan spesifisitasnya dengan menggunakan BLAST primer. ${ }^{13,14}$ Sintesis primer dilakukan oleh EUROGENTECAIT, Singapore.

DNA diamplifikasi menggunakan FastStart PCR Master, forward dan reverse primer. Total volume reaksi adalah $25 \mu \mathrm{L}$, yang terdiri dari 3,75 $\mu \mathrm{L}$ untuk masing-masing primer $(5 \mu \mathrm{M}), 1 \mu \mathrm{L}$ templat, $12,5 \mu \mathrm{L}$ PCR Master Mix dan $4 \mu \mathrm{L}$ $\mathrm{ddH}_{2} \mathrm{O}$. Siklus termal berlangsung sebanyak 40 siklus yang terdiri dari: denaturasi DNA pada suhu $96^{\circ} \mathrm{C}$ selama 30 detik, penempelan primer pada suhu $60^{\circ} \mathrm{C}$ selama 30 detik, dan pemanjangan pada suhu $72^{\circ} \mathrm{C}$ selama 2 menit.

DNA dimurnikan menggunakan illustra $^{\mathrm{TM}}$ PCR DNA and Gel Band Purification Kit menurut prosedur yang dikeluarkan oleh produsen.

Sebanyak $10 \mu \mathrm{L}$ sampel yang telah dicampur dengan $2 \mu \mathrm{L}$ loading dye, bersama dengan $2 \mu \mathrm{L}$ DNA ladder (100 bp) diaplikasikan pada $0,8 \%$ gel agarose, mengandung $\mathrm{EtBr}$ dengan konsentrasi akhir $0,5 \mathrm{ppm}$. Pada gel yang direndam dalam bufer TAE 1x, diberikan arus listrik $100 \mathrm{~V}$ selama \pm 60 menit, kemudian gel divisualisasi dengan pendedahan sinar UV.

Urutan nukleotida ditentukan menggunakan Big Dye Terminator V3.1 Cycle Sequencing Kit oleh Applied Biosystem 3130 Genetic Analyzer. Total volume reaksi adalah $20 \mu \mathrm{L}$, yang terdiri dari $3,75 \mu \mathrm{L}$ primer $(5 \mu \mathrm{M}), 1 \mu \mathrm{L}$ templat, $8 \mu \mathrm{L}$ BigDye Ready Reaction Mix dan 7,25 $\mu \mathrm{L} \mathrm{dd}_{2} \mathrm{O}$. Siklus termal berlangsung sebanyak 40 siklus, terdiri atas denaturasi DNA $\left(96^{\circ} \mathrm{C} ; 30^{\circ}\right)$, penempelan primer $\left(60^{\circ} \mathrm{C} ; 30^{\prime \prime}\right)$, dan pemanjangan $\left(72^{\circ} \mathrm{C} ; 2^{\prime}\right)$.

Sekuens gen smt dirakit (assamble) dengan menggunakan perangkat lunak $A T G C$ sequencing analysis versi 4.0 (ABI Prism), lalu nukleotida penyusunnya dikoreksi secara langsung.

Urutan nukleotida gen smt Geobacillus sp. 20k dirujuk ke Gene Bank untuk mengetahui kesamaannya dengan gen dan protein lainnya, terutama berkaitan dengan sintesis selenoprotein, menggunakan analisis BLASTn, BLASTx, dan BLASTp. Urutan nukleotida dideduksi menjadi urutan asam amino menggunakan program Translate Tool yang tersedia online, sebelum dilakukan pencarian homologi menggunakan BLASTp. ${ }^{15}$

\section{Hasil}

Identifikasi gen smt pada Geobacillus sp. 20k dimulai dengan penelusuran pada Gene Bank untuk mendapatkan informasi gen smt. Sekuens gen smt A. bisulcatus yang diperoleh dari basis data (Accession No. AJ131433) kemudian dikonfirmasi menggunakan program basic local alignment search tool (BLAST). Hasil pencarian homologi menunjukkan bahwa gen smt dan homolognya umumnya terdapat pada tumbuhan yang kaya selenium, antara lain: $A$. bisulcatus, teh (Camelia chinensis), dan Ab. thaliana dengan kesamaan lebih dari 85\% (Tabel 1).

Pada bakteri, gen tersebut memiliki domain mirip metiltransferase hingga $\pm 60 \%$, misalnya dengan homosistein metiltransferase pada Bacillus pumilus, Clostridium acetobutylicum, dan Streptococcus mutans (Tabel 1).

Primer spesifik yang dapat berikatan serta menginisiasi amplifikasi DNA target didesain untuk amplifikasi gen smt pada templat DNA berdasarkan sekuens gen smt A. bisulcatus. Primer yang direkomendasikan, disarikan pada Tabel 2 .

Fragmen DNA target berukuran 190 base pair telah berhasil diamplifikasi (Gambar 1) dengan urutan nukleotida, sebagai berikut:

CGTACATGCGTTCATCCGAGGGGTAAGAC

Tabel 1 Hasil Pencarian Homologi Gen smt A. bisulcatus

\begin{tabular}{llc}
\hline \multicolumn{1}{c}{ Organisme } & \multicolumn{1}{c}{ Gen } & Homologi \\
\hline Astragalus bisulcatus & Selenosistein metiltransferase (smt) & 100 \\
Teh (Camelia sinensis) & Selenosistein metiltransferase (smt) & 85 \\
Arabinopsis thaliana & Homosistein S-metiltransferase (hmt2) & 86 \\
Jagung (Zea mays) & Homosistein S-metiltransferase (hmt3) & 84 \\
Padi (Oryza sativa) & cDNA clone:J013044M21 & 83 \\
Anggur (Vitis vinifera) & hypothetical protein LOC100264835 & 84 \\
Sawi (Brassica oleracea) & Homosistein S-metiltransferase (hmt2) & 84 \\
Bacillus pumilus SAFR-032 & Homosistein S-metiltransferase & 64 \\
Clostridium acetobutylicum ATCC 824 & Possible Homosistein S-metiltransferase & 68 \\
Streptococcus mutans UA 159 & Putative metiltransferase & 63 \\
\hline
\end{tabular}


Tabel 2 Karakteristik Primer Gen smt

\begin{tabular}{cccccc}
\hline OLIGO & Awal & Panjang & $\begin{array}{c}\text { Melting } \\
\text { Temperature }\end{array}$ & \%GC & Sekuens \\
\hline Forward Primer & 271 & 20 & 59,97 & 45 & $5^{\prime}$ CAAGCCACCATTCAAGGTTT3' \\
Reverse Primer & 465 & 20 & 59,92 & 50 & 5'CCCTACTGATCCCGCAATTA3' \\
\hline
\end{tabular}

Tabel 3 Hasil Pencarian Homologi terhadap Sekuens Fragmen Gen smt Geobacillus sp. 20k

\begin{tabular}{llc}
\hline \multicolumn{1}{c}{ Protein } & \multicolumn{1}{c}{ Organisme } & Homologi (\%) \\
\hline Esterase/lipase/tioesterase & Bacillus lichineformis & 100 \\
Karboksilesterase & Bacillus pumilus ATCC 7061 & 95 \\
Karboksilesterase & Bacillus pumilus SAFR-032 & 93 \\
Thermostable carboxylesterase Est30 & Bacillus coahuilensis m4-4 & 90 \\
Thermostable carboxylesterase Est30 & Geobacillus sp. G11MC16 & 88 \\
Thermostable carboxylesterase Est30 & Geobacillus thermodenitrificans & 88 \\
Karboksilesterase & Geobacillus stearothermophilus & 90 \\
Seleno metiltransferase & Astragalus bisulcatus & 83 \\
\hline
\end{tabular}

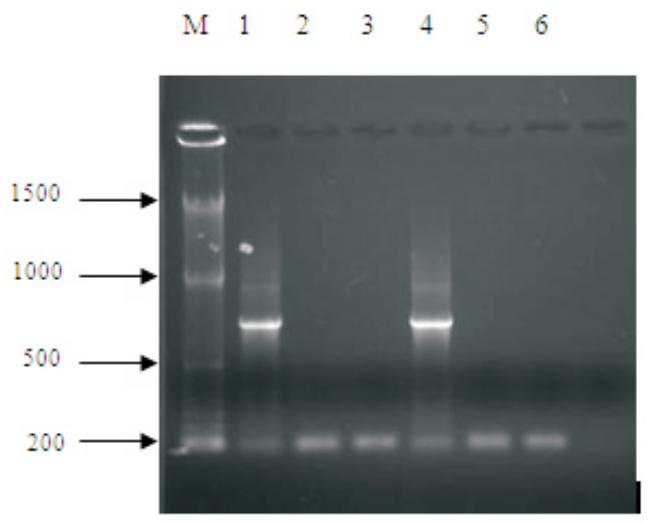

Gambar 1 Hasil Amplifikasi Fragmen DNA yang Berukuran Sekitar 190 bp

Keterangan: $\mathrm{M}=$ DNAladder, Lane 2 dan $5=$ produk $\mathrm{PCR}$ dengan primer smt

Tabel 4 Urutan Asam Amino Hasil Translasi Sekuens DNA dan BLAST

\begin{tabular}{|c|c|}
\hline Translasi protein & $\begin{array}{c}\text { Homolog } \\
\end{array}$ \\
\hline 3'5' Frame 1 & ref|YP 001127089.1| karboksilesterase termostabil \\
\hline R F P Y Stop S R N Y K K F E G K T A E Q I D & Est30 [Geobacillus thermodenitrificans NG80-2] (88\%) \\
\hline A E Met E E F K K T P Met N T L K A L Q D L & dan G. stearothermophilus ATCC7954 (90\%) \\
\hline I A D V R E H V D Met I Y S P T F V V Q A R & \\
\hline H D H Met I N T H C Q A T I Q G L S T D P A I & \\
\hline R Met H G S T L I C L T P R Met N A C T & \\
\hline 5'3' Frame 1 & ref|YP_001181019.1| tRNA adenililtransferase \\
\hline R T C VH P R G K T Y E R A P Met H S N C G & [Caldicellulosiruptor saccharolyticus] (63\%) \\
\hline I S R Stop T L N G G L T V R I N H Met I V A & \\
\hline R L H D K C R R I D H V H Met L S D I G N Q & \\
\hline I L Q C F Q R V HRRFFEFFHLSVNLL & \\
\hline R C L A F K F L I I A G S V G K P & \\
\hline
\end{tabular}

ATATGAGCGTGCTCCCATGCATTCTAATTG CGGGATCAGTAGATAAACCTTGAATGGTG GCTTGACAGTGCGTATTAATCATATGATCG TGGCGCGCCTGCACGACAAATGTAGGCG
AATAGATCATGTCCACATGCTCTCTGACAT CGGCAATCAAATCCTGCAGTGCTTTCAAC GTGTTCATCGGCGTTTTTTTGAATTCTTCC ATCTCAGCGTCAATCTGCTCCGCTGTCTT 


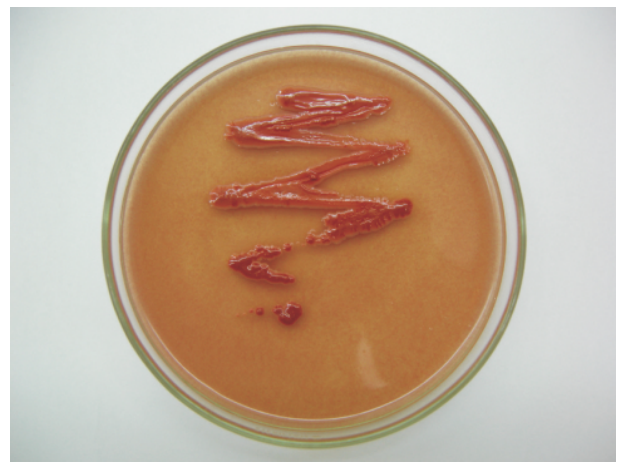

Gambar 2 Koloni Geobacillus sp. 20k pada Media yang Disuplementasi Se

\section{GCCTTCAAATTTCTTATAATTGCGGGATCA GTAGGGAAACCT.}

Hasil pencarian homologi pada basis data menunjukkan bahwa sekuens parsial gen smt Geobacillus sp. 20k mempunyai kemiripan dengan bagian dari gen smt A. bisulcatus (83\%). Fragmen tersebut juga serupa dengan bagian dari enzim esterase atau karboksilesterase yang termostabil pada bakteri termofilik, antara lain: Geobacillus sp, Geobacillus thermodenitrificans, dan Geobacillus stearothermophilus (Tabel 3).

Hasil tersebut dikonfirmasi oleh pencarian homologi menggunakan BLASTp yang urutan nukleotidanya terlebih dahulu dideduksi menjadi urutan asam amino penyusunnya, teridentifikasi sebagai bagian dari enzim termofilik dengan tingkat kesamaan 88-90\% (Tabel 4).

Prediksi Geobacillus sp. 20k memiliki gen yang mirip bagian gen seleno metiltransferase, dikonfirmasi oleh hasil kultur isolat tersebut pada media yang disuplementasi selenium. Bakteri tumbuh sebagai koloni berwarna merah (Gambar 2).

\section{Pembahasan}

Gen smt memiliki domain mirip metiltransferase $\pm 60 \%$ pada bakteri. Hal tersebut dapat disebabkan sifat kimia selenium dan sulfur serupa, sehingga toleransi selenium kemungkinan juga diatur oleh gen-gen yang terlibat dalam metabolisme sulfur. ${ }^{18}$ Bagian yang serupa diduga merupakan bagian yang bertanggung jawab untuk metiltransferase, sementara bagian yang berbeda merupakan bagian variabel dan mungkin spesifik untuk proses pengikatan selenium.

Primer spesifik yang digunakan untuk amplifikasi gen $s m t$ memenuhi persyaratan primer yang baik, yaitu panjang kedua primer antara 18-25 pasang basa yaitu 20 nukleotida; ${ }^{9}$ perbedaan panjang kedua primer $<$ tiga pasang basa; perbedaan $\mathrm{Tm}$ kedua primer kurang dari $5^{\circ} \mathrm{C}$, yaitu $0,05^{\circ} \mathrm{C}$; komposisi $\mathrm{G}+\mathrm{C}$ antara $40-60 \%$, yaitu $45 \%$ dan $50 \%$. Primer memiliki tidak lebih dari tiga pasang basa yang berkomplemen, sehingga kecil kemungkinan terbentuk dimer primer. Persyaratan yang tidak dipenuhi adalah pembentukan G-C clump, sedangkan basa pada ujung 3' berupa $\mathrm{G}$ atau $\mathrm{C}$ agar stabilitas ikatan basa cukup kuat, karena G-C memiliki 3 ikatan hidrogen, dibandingkan dengan A-T yang hanya dua ikatan. Selain itu, berdasarkan BLAST primer, primer bersifat spesifik karena tidak ada sekuens gen yang tingkat kesamaannya signifikan dengan primer gen smt (data tidak ditampilkan), sehingga fragmen DNA target yang berukuran 190 base pair berhasil diamplifikasi.

Koloni berwarna merah pada kultur Geobacillus sp. 20k ini menunjukkan bahwa bakteri dapat mereduksi senyawa selenium menjadi selenium elemental. ${ }^{16}$ Mekanisme ini merupakan indikasi bahwa Geobacillus sp. 20k mampu mengakumulasi dan detoksifikasi selenium. ${ }^{8}$ Hal tersebut sesuai hasil penelitian terdahulu yang mengungkapkan Geobacillus sp. $20 \mathrm{k}$ dapat mengakumulasi selenium dari lingkungan sebesar $1,0031 \mathrm{ppm}^{17}$

Selenium diduga dapat diakumulasi oleh Geobacillus sp. 20k dalam bentuk termetilasi, yang tidak toksik bagi bakteri, seperti pada organisme pengakumulasi selenium lainnya. ${ }^{18}$ Dugaan tersebut berdasarkan informasi bahwa tumbuhan yang kaya selenium, mengubah selenium yang berpotensi toksik menjadi tidak toksik melalui mekanisme metilasi, membentuk MSC yang sangat efektif sebagai antikanker. ${ }^{11,19}$ Asam amino ini hanya dihasilkan oleh organisme 
yang kaya selenium, dengan perantaraan enzim SMT disandi oleh gen smt. ${ }^{1,18}$ Oleh karena itu, diprediksi bahwa Geobacillus sp. 20k memiliki gen yang homolog dengan smt. Prediksi ini diperkuat oleh hasil penelitian yang menunjukkan bahwa Geobacillus sp. 20k mampu membunuh sel kanker darah 67\% dan sel kanker limfe 37\%.

Ada hal menarik yang terungkap saat sekuens DNA gen smt Geobacillus sp. 20k dideduksi ke dalam urutan asam amino penyusun proteinnya. Analisis BLAST terhadap hasil deduksi sekuens parsial tersebut menunjukkan bahwa protein yang terbentuk dari fragmen DNA 3' ke 5' memiliki kemiripan dengan bagian dari enzim karboksilesterase yang termostabil dari $G$. thermodenitrificans (88\%) dan G. stearothermophilus $(90 \%)$. Fragmen DNA 5' ke 3' memiliki kemiripan (63\%) dengan tRNA adenililtransferase-Se bakteri termofilik Caldicellulosiruptor saccharolyticus (Tabel 4). Informasi tersebut memberi gambaran bahwa dari fragmen DNA yang diamplifikasi dari isolat bakteri termofilik Geobacillus 20k, diperoleh peluang adanya gen dan protein yang serupa dengan gen smt dan enzim SMT $A$. bisulcatus. Hal ini berdasarkan setidaknya dari teridentifikasinya fragmen DNA untuk domain enzim karboksilesterase yang termostabil dan enzim adenililtransferase-selenium, yang mirip dengan gen smt $A$. bisulcatus yang berkaitan dengan metabolisme selenium.

Hasil analisis sekuens parsial gen smt Geobacillus sp. 20k, bersama dengan kemampuan Geobacillus sp. 20k melawan sel kanker, dan mengakumulasi selenium, ${ }^{17}$ yang dikonfirmasi oleh tumbuhnya koloni bakteri berwarna merah pada medium disuplementasi selenium, membuka peluang untuk memanfaatkan Geobacillus sp. 20k sebagai sumber selenium nontoksik untuk terapi kanker.

Penelitian ini dapat disimpulkan bahwal. Geobacillus sp. 20k memiliki bagian dari gen seleno metiltransferase $(\mathrm{sm} t) \mathrm{A}$. bisulcatus yang berukuran 190 base pair. Sekuen DNA fragmen gen smt pada Geobacillus sp. 20k memiliki kesamaan dengan bagian gen smt A. bisulcatus (83\%), karboksilesterase $(\sim 90 \%)$, dan tRNA adenililtransferase $(63 \%)$.

Hasil penelitian ini dapat dimanfaatkan untuk memberdayakan enzim SMT yang disandi oleh gen smt pada Geobacillus sp. 20k sebagai upaya untuk memproduksi MSC, yang merupakan senyawa selenium nontoksik untuk terapi kanker.

\section{Daftar Pustaka}

1. Ellis DR, Sors TG, Brunk DG, Albrecht C, Orser $\mathrm{C}$, Lahner $\mathrm{B}$, et al. Production of Semethylselenocystein in transgenic plants expressing selenocysteine methyltransferase. BMC Plant Biol. 2004 Jan;4(1):1-11.

2. Kiefer D. Getting serious about selenium. Life Extension Magazine Report. 2004. [diunduh 15 januari]. Tersedia dari: http:www.lef.org/.

3. Johansson L, Gafvelin G, Arner ESJ. Selenocysteine in protein properties and biotechnological use. Biochim. Biophys Acta. 2005;XX:1-13.

4. El-Bayoumy K, Sinha R. Molecular chemopreventive by selenium: a genomic approach. Mutation Research [Online Journal] 2005 [diunduh 15 januari 2008]. Tersedia dari www.sciencedirect. com.

5. Institute of Medicine, Food \& Nutrition Board. Dietary reference intake: vitamin $C$, selenium, and carotenoids. Washington D.C: National Academy Press: 2000.

6. Lobinski R, Edmonds JS, Suzuki KT, Uden PC. Species-species determination of selenium compounds in biological material. Pure Appl Chem. 2000;72(3):447-61.

7. Dong Y, Ganther HE, Stewart C, Ip C. Identification of molecular target associated with selenium-induced gowth inhibition in human breast cells using cDNA microarrays. Cancer Res. 2002;62:708-14.

8. Whanger PD. Selenium and its relationship to cancer. Br J Nutr. 2004;91:11-28.

9. Finley JW, Ip C, Lisk DJ, Davis CD, Hiunzte KJ, Whanger PD. Cancer-protective properties of high selenium broccoli. J Agric Food Chem. 2001; 49:2679-83.

10. Lyi SM, Heller LI, Rutzke M, Welch RM, Kochian LV, Li L. Molecular and biochemical characterization of the selenocysteine Se-methyltransferase gene and Se-methylselenocysteine synthesis in Broccoli. Plant Physiol. 2005;138(1):409-20.

11. Neuhierl B, Thanbichler M, Lottspeich F, Montana A, Boock. A family of S-methylmethionine-dependent thiol/selenol methyltransferases: role in selenium tolerance and evolutionary relation. J Biol Chem. 1999;274(9):5407-14.

12. NCBI. National Center for Biotechnology Information HomePage. [diunduh 8 Agustus 2008]. Tersedia dari: http://www.ncbi.nlm.nih. gov.

13. Rozen S, Skaletsky HJ. Primer3 on the WWW for general users and for biologist programmers. Dalam: Krawetz S, Misener S, penyunting. Bioinformatics methods and protocols: methods in molecular biology. Totowa: Humana Press: 2000. hlm. 365-86. 
14. NCBI. National Center for Biotechnology Information HomePage. [diunduh 8 Agustus 2008]. Tersedia dari: http://biotools.umass med.edu/cgi-bin/primer3plus/.

15. Swiss Institute of Bioinformatics (SIB). ExPASy Proteomics Server. [diunduh 12 Mei 2009]. Tersedia dari: http://us.expacy.org/.

16. Zhang LH, Abdel-Ghany SE, Freeman JL, Ackley AR, Schiavon M, Pilon-Smits EAH. Investigation of selenium tolerance mechanisms in Arabidopsis thaliana. Physiol Plant. 2006; 128:212-23.
17. Handayani. Penurunan ekspresi gen pho85 sel apoptosis Saccharomyces cerevisiae oleh eks-trak air daun ciplukan 33NHR dan Geobacillus sp. 22a [Skripsi]. Bogor: IPB; 2006.

18. Pickering IJ, Wright C, Bubner B, Ellis D, Persans MW, Yu EY, et al. Chemical form and distribution of selenium and sulfur in the sele-nium hyperaccumulator Astragalus bisulcatus. Plant Physiol. 2003;131:1457-60.

19. Rayman MP. The Importance of selenium to human health. Lancet. 2000;356:233-41. 